\title{
UM DIÁLOGO POSSÍVEL ENTRE A PRÁTICA HISTORIOGRÁFICA E OS PARADIGMAS RELATIVÍSTICOS E QUÂNTICOS DA CIÊNCIA
}

\section{A Possible Dialogue between Historiographic Practice and Relativistic and Quantum Paradigms of Science}

Prof. Dr. Moisés Romanazzi Tôrres Professor Titular do Departamento de Ciências Sociais (DECIS) da Universidade Federal de São João del-Rey (UFSJ) Programa de Pós-Graduação em História da UFSJ (PPGHIS-UFSJ) ORCID: https://orcid.org/0000-0003-2773-4584

Email: mrtorres@ufsj.edu.br

Recebido em: 17/07/2020

Aprovado em: 20/12/2020

Resumo: Este artigo, após caracterizar a História como uma ciência e assim reivindicar um diálogo necessário com a relatividade e o quantum, propõe três pontos de ruptura com a prática historiográfica empregada hoje em dia, considerada anacrônica em relação aos paradigmas da cientificidade contemporâneos e com potencial mesmo de afastar a História da Ciência.

Palavras-Chave: Prática Historiográfica; Diálogo com a Relatividade e o Quantum; Paradigmas Contemporâneos da Ciência.

Abstract: This article, after characterizing History as a science and thus claiming a necessary dialogue with relativity and quantum, proposals three points of rupture with the historiographical practice used today, considered anachronistic in relation to the current paradigms of scientificity and with the potential to remove the History of Science.

Key-Words: Historiographic Practice; Dialogue with Relativity and Quantum; Contemporary Paradigms of Science. 


\section{Introdução: Uma História Anacrônica - Avanços e Limitações do Pensamento Histórico no Século XX}

Que a História é uma ciência, parece não haver dúvida. Clifoord Geertz (1989, p. 126) salienta existir quatro perspectivas segundo as quais os homens compreendem a realidade: a do senso comum, a religiosa, a estética e a científica. Vejamos primeiro o que caracteriza as perspectivas do senso comum, a religiosa e a estética, depois, o quanto se diferenciam da perspectiva científica e, por fim, como a História se integra na Ciência.

Segundo Geertz (1989, pp. 126 - 128), a perspectiva do senso comum corresponde à simples aceitação do mundo, dos seus objetos e processos nas formas exatas como se apresentam, como parecem ser. Seu motivo é pragmático, nasce do desejo de atuar sobre o mundo com o fim de dirigi-lo em função de seus propósitos práticos, dominá-lo ou, caso isto se torne impossível, ajustar-se a ele. Já a religiosa se baseia no seguinte axioma: aquele que tiver de saber precisa primeiro acreditar. Portanto, o dado fundamental nela é a fé. Baseado na fé, a perspectiva religiosa repousa no sentido do verdadeiramente real e as atividades simbólicas da religião enquanto sistema cultural se dedicam a produzi-lo, buscando torná-lo inviolável pelas revelações discordantes da experiência secular. Por fim, a estética implica numa insistência ávida nas aparências, trata-se de um açambarcamento das superfícies, a contemplação das qualidades sensoriais sem os seus significados habituais de, por exemplo, "aqui está a cadeira" ou "aquele é o meu telefone". Ou seja, os significados deixam de importar mediante a eloquência especial dada às aparências sensoriais, em outras palavras, implica na busca da beleza.

A perspectiva científica difere do senso comum porque seus marcos são de outra natureza. Como ainda salienta Geertz (1989, p. 127), nela é a dúvida deliberada e a pesquisa sistemática o que importa, corresponde, pois, a suspensão do motivo pragmático em função da observação desinteressada, constituindo uma tentativa de analisar o mundo em termos de noções e conceitos formais, problematizando assim, cada vez mais, aquilo que ao senso comum bastava: as concepções informais.

Ainda que as perspectivas religiosa e estética impliquem também numa suspensão do motivo pragmático, a perspectiva científica delas difere igualmente, isto porque, 
enquanto para a Religião o que importa é a fé e toda sua atividade implica em afirmá-la perante tudo e todos e, para a Arte, o que importa são as aparências/superfícies sensorializadas, constituindo nisto uma procura incessante pelo belo; para a Ciência, tudo se resume ao conhecimento dito científico, portanto, a busca crítico-metodológica da verdade é o que a motiva.

A prática historiográfica, constituída a partir de fontes tratadas pelo senso crítico do historiador com apoio em uma metodologia determinada, além de não ser pragmática e, portanto, diferente do senso comum, não é também, evidentemente, regida por crenças religiosas ou sensos estéticos. Antes, enquadra-se perfeitamente na Ciência, sendo instaurada a partir de dúvidas deliberadas, estabelecida na pesquisa sistemática, baseada em noções e conceitos formais e, ainda que o sentido de verdade tenha mudado ao longo do tempo, seu objetivo foi sempre, inegavelmente, o de conhecer efetivamente a realidade histórica.

Não é atoa, portanto, que, do Positivismo à Microhistória, a perspectiva científica da historiografia seja defendida amplamente. Nem mesmo na Primeira e na Segunda Geração dos Annales, com a concepção, então introduzida, de que a História é uma construção dos historiadores, tal consenso foi abalado, isto porque os annalistas souberam, aliás bastante bem, desenvolver tal relativismo dentro de uma epistemologia determinada, a da objetividade enfraquecida pela subjetividade inerente ao conhecimento.

Como explica Adam Schaff (1991, pp. 280 e 281), o sujeito desempenha um papel ativo no conhecimento histórico já por estar implicado nele. O dado fundamental é que o sujeito é sempre quem conhece e, portanto, um conhecimento inteiramente objetivo seria a-humano ou sobre-humano. Como textualmente salienta: "a objetividade dita pura é uma ficção; o fator subjetivo é introduzido no conhecimento histórico pelo próprio fato da existência do sujeito que conhece" (SCHAFF, 1991, p. 282).

Consequentemente, a objetividade desse conhecimento contém sempre uma dose de subjetividade. Há, no entanto, segundo Schaff (1991, pp.281 e 283), duas subjetividades. Com efeito, é flagrante a distinção entre o subjetivo sob o ponto de vista epistemológico, o que não possui um valor cognitivo universal e o subjetivo sob o ponto de vista ético (ou melhor, antiético) o que é emocionalmente colorido e, por este motivo, parcial. A primeira subjetividade é a "boa", pois provém da essência do conhecimento 
enquanto relação subjetiva-objetiva e do papel ativo do sujeito no processo cognitivo; a segunda é a "má", pois subjetividade que deforma o conhecimento em virtude de fatores como o interesse e a parcialidade. Portanto, o objetivo científico da objetividade do conhecimento histórico deve ser o de ultrapassar a subjetividade "má". Dito de outro modo, construção, sim, mas imparcialmente.

É exatamente por isto que se ater à análise crítica e metodológica das fontes é a garantia de objetividade que, simultaneamente, permite e traduz a cientificidade da História.

Penso, no entanto, não caber então a visão de historiadores como Ciro Flammarion Cardoso. Com efeito, para Cardoso (1981, p.43), a História se distinguiria das demais Ciências por ser uma "ciência em construção". Naturalmente que este autor reconhece que toda e qualquer ciência se encontra em construção já que não se buscam mais verdades absolutas e eternas. Mas, conforme explica, a História seria uma "ciência em construção" no sentido de "que a conquista de seu método científico não é completa, que os historiadores ainda estão descobrindo os meios de análise adequados ao seu objeto" (CARDOSO, 1981, p. 43).

Porém, qual é a ciência em que o método científico esteja completo? Qual aquela em que os cientistas não estejam ainda descobrindo os meios de análise adequados ao seu objeto? As ideias de completeza do método e a de definição dos meios de análise, quando existem, não passam de mitos, seja na História, na Física, na Biologia, etc. Como que se pode falar de um método completo ou qualquer outra completeza se o pensamento é apenas representativo? Como que se pode falar de meios de análise definitivos se a própria Ciência tem sua historicidade e ela, evidentemente, está em curso?

O problema que realmente existe na relação entre História e Ciência é bem diferente. Como a História é uma ciência como qualquer outra, deve naturalmente estar atenta aos paradigmas que regem, em sua época, a cientificidade como um todo. Isto a História sem dúvida fez na época do positivismo.

Tal movimento de pensamento, que dominou uma parte significativa da cultura científica europeia, em suas manifestações filosóficas, políticas, pedagógicas e historiográficas, e com grandes repercussões na literatura, de cerca de 1840 até às 
vésperas da Primeira Guerra Mundial, corresponde a uma radicalização dos paradigmas da chamada Ciência Clássica, ou seja, cartesiana e newtoniana, no sentido de enaltecer a razão e a Ciência perante as demais manifestações da vida e pensamento humanos.

Como estudam Reale e Antiseri (2005, p. 296), o positivismo se desenvolveu a partir de tradições culturais diferentes. Na França, seguiu pari passu ao racionalismo que vai de Descartes ao iluminismo; na Inglaterra, inseriu-se na tradição empirista e utilitarista e, em seguida, entrelaçou-se com a teoria evolutiva darwinista; na Alemanha, assumiu a forma de cientificismo e de monismo materialista; na Itália, especialmente com Roberto Ardigò, aprofundou suas raízes no naturalismo renascentista.

Apesar de tais diferenças, o positivismo possui traços comuns que o caracteriza enquanto um movimento de pensamento particular. A começar pelo fundamento iluminista de sua concepção de Ciência: consideram os fatos empíricos como a única base do conhecimento verdadeiro. Mas também, novamente segundo Reale e Antiseri (2005, pp. 297 e 298), foi o positivismo como um todo que reivindicou o primado da Ciência. Com efeito, para eles, conhece-se apenas aquilo que as ciências nos dão a conhecer, uma vez que o único método de conhecimento é o das Ciências Naturais. Mas tal método (identificado com as leis causais e seu domínio sobre os fatos) não vale apenas para o estudo da Natureza, mas igualmente para o estudo da sociedade. Por isto, fundou a Ciência dos "fatos naturais" que são as relações humanas e sociais, a Sociologia, especialmente através do pensamento de Émile Durkeim. Porém, o positivismo como um todo não apenas afirma a unidade do método científico e seu primado como instrumento cognoscitivo, mas, marcado por um otimismo sem limites, também exalta a Ciência como a única via capaz de, em longo prazo, resolver todos os problemas existenciais e sociais que atormentam a humanidade.

Na historiografia, como observa Elias Thomé Saliba (2013, p. 312), o positivismo se fez presente pela crença de que o sujeito cognitivo, no caso o historiador, é neutro e ausente, quase como um copista idôneo ou compilador disciplinado dos grandes conjuntos de documentos e arquivos, praticando aquele "grandioso e épico esquecimento de si próprio" do sonho, que acabou se tornando a prática, de Langlois e Seignobos no célebre breviário Introduction aux Études Historiques (1898).

Mas também, como estuda Philippe Ariès (1989, pp. 47 e 64), implicou no desenvolvimento de uma escola histórica fundada sobre a noção de que as diferenças 
dos tempos são uma aparência, que, como as mesmas causas repetem os mesmos efeitos, os homens não mudaram, suas ações se repetem, e então é o estudo dessas repetições que permite conhecer as leis da política. Com efeito, a história positivista é sobretudo uma história política factual, baseada nos grandes homens e em seus grandes feitos. Contudo, seu traço mais essencial é mesmo o papel que o historiador deve ter frente a seu objeto específico: o de, sob as aparências diversas dos tempos, reencontrar o homem eterno, sempre igual a si mesmo. Os sentimentos fundamentais do homem não variaram: são sempre o amor, o ódio, a ambição, etc. Igual identidade se encontra na vida das cidades. A política, base da história, é por isto igualmente repetitiva: monarquia, tirania, aristocracia, democracia, demagogia caracterizam os regimes desde Platão e Aristóteles até Hitler e Stalin.

Uma primeira reação ocorreu através do marxismo. Porém é preciso perguntar: reação até que ponto? Não se vê no marxismo nenhum incômodo fundamental em relação à neutralidade e ausência do historiador, antes tal atitude serve de confirmação à cientificidade da História. Sem dúvida que a história marxista pôs a economia no lugar da política, contudo, nisto apenas trocou um determinismo por outro. Também, substitui o enfoque aos grandes homens e seus grandes feitos pelas lutas de classes, contudo, a visão de fundo continua a ser bastante simplista, já que desconhece ou relega ao segundo plano todas as demais heterogeneidades sociais.

Ainda, como novamente salienta Ariès (1989, p. 66), os motivos tanto do marxismo quanto do positivismo não são determinados, não de fato, pelas condições particulares do tempo e do espaço, antes atestam que os fenômenos são regidos por leis que se deduzem de sua repetição no curso da história. Um tende ao cataclismo revolucionário de acordo com a evolução econômico-técnica, outro tende à conservação, reduzindo os fatores de diversidade a um tipo médio e constante, mas ambos os enfoques ignoram a verdadeira preocupação histórica, uma consciência, global ou particular, do passado. O que, no entanto, deixa estupefato o próprio Ariès: "como que os que tinham uma experiência concreta e pessoal de sua história puderam se contentar com uma imagem tão deformada e tão abstrata da grande história?” (ARIÈS, 1989, p. 66).

Um movimento de reação realmente amplo e radical ocorreu apenas com os Annales. Peter Burke (1992, pp. 10 a 15) o resume em seis pontos: 
Primeiro, só então a história passou a se interessar por toda a atividade humana. $\mathrm{O}$ relativismo cultural nisto implícito se deve ao fato de que a base filosófica da chamada Nova História é a ideia que a realidade é social ou culturalmente determinada. Daí a convergência entre a História e as Ciências Sociais e toda uma interdisciplinaridade a partir de então desenvolvida.

Segundo, passa-se de uma mera narrativa dos acontecimentos a uma análise das estruturas.

Terceiro, enquanto a história tradicional oferece uma visão de cima, pois centrada nos grandes homens e seus grandes feitos; a chamada Nova História se preocupa sobretudo com uma "história vista de baixo", isto é, com as opiniões das pessoas comuns e com sua experiência de mudança social.

Quarto, ao invés das fontes do historiador se resumirem a documento oficiais (ou seja, emanados dos governos e instituições e preservados em arquivos); toda uma pluralidade de fontes passa a ser utilizada. Os registros oficiais em geral expressam o ponto de vista oficial. Para saber também das atitudes, por exemplo, dos rebeldes e hereges, é preciso suplementar tais registros por outros tipos de fontes. De qualquer modo, preocupados com uma variedade bem maior de atividades humanas, os historiadores devem examinar uma maior variedade de evidências.

Quinto, quando um historiador positivista se pergunta, por exemplo, a razão de Brutus ter apunhalado César, ele está preocupado em o que Brutus pensou, em o que fez com que ele decidisse apunhalar César. Já os Annales consideram que este modelo de explicação histórica falha na avaliação da variedade de questionamentos dos historiadores, com frequência preocupados, tanto com os movimentos coletivos, quanto com as ações individuais, tanto com as tendências, quanto com os acontecimentos.

Sexto, o princípio relativista epistemológico já comentado. Com efeito, a perspectiva de neutralidade e objetividade do "paradigma" tradicional é vista como irrealista pelos annalistas. Para eles, sempre olhamos o passado de um ponto de vista culturalmente determinado. Tal perspectiva se aplica, na verdade, tanto à escrita da história quanto aos seus objetos. As mentes não refletem diretamente a realidade, antes percebemos o mundo através de uma estrutura de convenções, esquemas e estereótipos, num entrelaçamento que varia de uma cultura para outra. 
Mas precisamos avançar para além dos Annales ao menos em dois pontos. As diferenças de olhar dos historiadores não têm apenas um fundo cultural, sendo necessariamente sociais, mas dependem igualmente de percepções pessoais, sendo também particulares. É justamente neste sentido que a História deve ser vista como construção. Cada historiador, portanto, distinto pessoalmente, produz, a partir da análise crítico-metodológica das fontes (o que é suficiente para garantir a cientificidade do relato como já dito), uma leitura própria, defensável perante leituras contraditórias, sendo que as diferenças se resolvem justamente no campo dialético de validação do conhecimento.

O mesmo a se dizer da sociedade. Com efeito, apesar da chamada Nova História ter colocado a realidade social e sua diversidade cultural no lugar dos determinismos político e econômico respectivamente do positivismo e do marxismo, ela acabou com isto produzindo um novo e grande determinismo, o sociocultural. Deste derivou ainda outro: o determinismo histórico. Seus frutos são a visão de uma sociedade essencialmente homogênea e a perspectiva de que os homens, uma vez que regidos por padrões sociais determinados culturalmente, são a expressão de sua época e lugar. Porém é evidente que toda e qualquer sociedade é na verdade um misto de homogeneidades e heterogeneidades. Ademais, se os homens fossem filhos bem comportados do seu tempo, a "roda" da História seria ilusão. Ora, são os homens os agentes da História, mas, uma vez condicionados pela contemporaneidade, isto resultaria, invariavelmente, em nenhum movimento diacrônico, nenhuma história.

Notem que não estou dizendo que todos os annalistas sejam deterministas socioculturais e históricos rigorosos. Minha crítica, direcionada à escola historiográfica e não a historiadores particulares, caracteriza-se por uma contestação à visão geral da qual cada historiador se apropriou num mais ou menos.

E tanto é verdade o que digo que foi este um dos motivos do próprio Movimento dos Annales ter sido também contestado. Na História Cultural de Roger Chartier as lutas de representações entre grupos sociais tomam o lugar da sociedade homogênea e na Microhistória mesmo estudos de casos particulares são objetos da História.

Contudo, não se produz jamais uma história dos indivíduos, o que, penso eu, deveria ser o grande objetivo da História. Roger Chartier até fala, volta e meia, em representações individuais, a Microhistória pode mesmo voltar-se para um indivíduo, 
mas ambas instrumentalizam apenas agrupamentos sociais. Ademais, tais agrupamentos são então tidos como homogêneos. Quer dizer, a visão geral é que a sociedade é heterogênea, mas enquanto um misto de grupos ou no máximo de subgrupos sociais homogêneos.

Em Chartier está tudo muito claro: o fio condutor são as lutas de representações que os grupos estabelecem entre eles no "ringue" social. Como salienta: "os mecanismos pelos quais um grupo se impõe ou procura se impor, a sua concepção do mundo social, os valores que são os seus e o seu domínio" (CHARTIER, 1990, p.17). Portanto, tais grupos são considerados homogêneos, pois, caso contrário, deveria Chartier dar atenção igualmente as lutas internas, de subgrupos e de indivíduos, em cada um desses grupos.

A Microhistória representa assim um avanço considerável, pois nela se encontra implícito, como aliás salienta Carlo Ginzburg (2007, p.269), uma afirmação de natureza ontológica: a realidade é necessariamente descontínua e heterogênea. Contudo, não se pode perder a visão de conjunto, portanto, as diversas microanálises devem ser recompostas sob a perspectiva da macrohistória, o que, penso eu, está certíssimo. Ao fazerem isto, os microhistoriadores permanecem atentos às heterogeneidades individuais, pois, de fato compreendem, como novamente aponta Ginzburg (2007, p. 277), que toda configuração social é o resultado da interação de incontáveis estratégias de indivíduos. Contudo, não encontram um meio prático de estabelecer todas essas estratégias e assim tendem a, no máximo, tomá-las enquanto representações de subgrupos que, assim, são tão homogêneos quanto os grupos de Chartier.

Mas passar da homogeneidade da sociedade à homogeneidade dos grupos e subgrupos sociais não resolve nada, pois nos mantemos sempre presos à analogia. É preciso, ao contrário, mudar o enfoque: da analogia para a anomalia. Contudo, não ficar presos na anomalia, pois neste caso apenas trocaríamos de grilhões. Antes, a partir da identificação das anomalias, alcançar igualmente as analogias. Façamos isto partindo dos indivíduos necessariamente. Afinal, são eles os agentes efetivos da História. Eis que, então, analisando através das famílias, dos subgrupos e grupos sociais, chegamos por fim à sociedade como ela de fato é, como já dito um misto de homogeneidades e heterogeneidades. Neste momento devemos, no entanto, empreender o caminho inverso: da sociedade aos grupos, subgrupos e famílias, e daí aos indivíduos. Este movimento 
pendular, que deve ser repetido tantas vezes quanto for necessário, é imprescindível para que compreendamos devidamente as três escalas em estudo: a da própria sociedade, a dos agrupamentos sociais parciais (famílias, subgrupos e grupos sociais) e a dos próprios indivíduos.

Consiste em se constituir o que chamo de Nanohistória. Ou seja, aquela realmente centrada nos indivíduos já que não os toma mais como representantes de grupos e subgrupos, mas como pessoas, procurando assim instrumentalizar suas particularidades. Então procura os recompor em suas famílias, recompostas por sua vez nos subgrupos, recompostos ainda nos grupos, recompostos por fim na sociedade. Baixando em seguida desde a sociedade até os indivíduos, e então pendulando até que a articulação entre as três escalas permita esclarecê-las devidamente, naturalmente de acordo com os recortes, objetivos e hipóteses da pesquisa proposta.

Sei que, então, todos devem estar se perguntando: como é possível alcançar os indivíduos? Já se preparam, então, para me censurar aberta e rigorosamente: não existem fontes que os iluminem! Mas naturalmente que numa visão determinística, isto é, baseada em definições, a Nanohistória não só não é possível, como soa ridícula. Contudo, se meus colegas estivessem atentos ao que a Mecânica Quântica ensina já desde a primeira metade do século passado, que a realidade deve ser vista probabilisticamente, e então ter assumido tal visão indeterminista, o problema estaria a muito resolvido. Considerando-se que, mediante a sociedade e aos agrupamentos sociais em que se encontram inseridos, seus indivíduos poderiam apenas manifestar, segundo o aspecto considerado, um número finito de possibilidades, basta então estabelecer quais são essas possibilidades para abrimos um caminho que nos permite uma maior aproximação com os indivíduos.

Por exemplo, nenhum historiador hoje em dia irá defender que os valores de um ateniense do século IV a. C. sejam os mesmos de um inglês do século XVIII, pois isto é anacrônico. Também não faz sentido, noutro exemplo, que, em meio à Revolução Russa, um bolchevique defenda ideias e práticas monárquicas e/ou burguesas, isto porque tal heterogeneidade não condiz com a homogeneidade de seu grupo. Portanto, consideramos essas alternativas como impossíveis. Contudo, por um lado, tanto os atenienses do século IV a. C. quanto os ingleses do século XVIII não têm entre eles a mesmíssima percepção dos valores sociais de suas épocas e lugares; por outro, não é 
porque bolcheviques são antimonárquicos e antiburgueses, que pensam exatamente do mesmo jeito em relação à Monarquia e a Burguesia. Com efeito, em relação a ambas as ideias, supor ao contrário seria ingênuo por demais! Consiste, portanto, em se determinar, tendo como parâmetro os recortes, objetivos e hipóteses da pesquisa, as diferentes possibilidades envolvidas em cada caso. Trata-se, pois, do trabalho prévio, aquele que fornece os dados que serão os instrumentos da Nanohistória.

Não ser orientado por uma perspectiva indetermista, probabilística é, no entanto, apenas um dos aspectos que tornam a historiografia praticada hoje em dia uma atividade científica anacrônica. Digo anacrônica porque em desacordo com os paradigmas que regem a Ciência Contemporânea, dados na Relatividade e na Mecânica Quântica. Como ainda se baseia nos paradigmas da Ciência Moderna, dita Ciência Clássica, isto é, no cartesianismo e, especialmente, no newtonianismo, tal anacronismo corresponde a um atraso, de pelo menos dois séculos, da Ciência História perante a Ciência como um todo.

Mas o problema não está apenas no dissabor de termos constituído uma História Anacrônica. Há igualmente um grave risco envolvido: o de afastar a História da Ciência.

É preciso entender que vivemos, ainda vivemos, uma época interparadigmática. Os novos paradigmas da relatividade e do quantum apresentam muitos elementos dissonantes entre eles (por exemplo, a visão probabilística da Mecânica Quântica era duramente criticada por Albert Einstein que, a este título, teria cunhado uma expressão que se tornou célebre: "Deus não joga dados com o Universo") e, portanto, a transição paradigmática só se completará quando for possível se estabelecer uma Teoria da Unificação. Esta vem sendo buscada desde a segunda metade do século passado, mas, ainda hoje, parece distante. Eis que então um precedente histórico nos assusta. Em outra época interparadigmática, a do Renascimento, acabou por triunfar uma ontologia mágica.

Como salienta Alexandre Koyré (1991, p. 46-48), o Renascimento foi uma das épocas menos dotadas de espírito crítico que o mundo conheceu. Época da mais completa e profunda superstição, em que a crença na magia e na feitiçaria se expandiram prodigiosamente, muitíssimo mais que na Idade Média. A explicação disto é bem simples. No aristotelismo havia um enorme número de coisas que não são 
possíveis e que, portanto, sabia-se serem falsas de antemão. Mas o Renascimento, empenhado em destruir a Física, a Metafísica e a Ontologia aristotélicas, mas sem ter nada para pôr em seu lugar (a reconstituição paradigmática ocorreu apenas na chamada Revolução Científica do século XVII), privou os homens de um critério para se decidir que a informação que se recebe de tal ou qual "fato" é verdadeira ou não. Ora, o homem é um animal crédulo por natureza, daí a destruição do pensamento medieval ter conduzido o Renascimento a uma credulidade sem limite.

Por que não supor então que vivemos também um perigo? Afinal, o fantasma da pós-modernidade nos assombra. Nele, no entanto, o risco é justamente o oposto: o da incredulidade sem limites. Conquanto, o resultado é o mesmo: por a Crença no lugar da Ciência.

Para a História, o problema consiste no fato de que a reação aos paradigmas clássicos da neutralidade e da objetividade, estabelecida no combate ao positivismo e ao marxismo por parte dos Annales, pode bem ser desvirtuada para a negação da cientificidade da História.

Como tanto os Annales quanto as demais correntes historiográficas atuais (História Cultural e Microhistória) foram estabelecidas enquanto desenvolvimentos específicos da disciplina História e guardando relações apenas com as disciplinas próximas da Sociologia e Antropologia, portanto, desconectadas do centro dos acontecimentos científicos e assim não norteadas pelos paradigmas relativísticos e quânticos, base da cientificidade contemporânea, talvez sua maior conquista, o do relativismo e subjetivismo inerentes a ideia da História enquanto construção, pode, no entanto, uma vez que a nau se encontra desgovernada, nos levar, caso os ventos pósmodernos assim comandem, ao extremo, que penso que ninguém deseja, de se pôr em dúvida ou mesmo se abandonar a busca da verdade, desligando assim a História da Ciência.

Já a partir das determinações estabelecidas pelos Annales em relação as fontes, criou-se o que Elias Saliba (2013, p. 319) chama de constituição de um "relativismo histórico marcado pelo descrédito da verdade". Como explica, não que as operações preliminares pelo crivo das quais os historiadores deveriam passar as fontes tenham desparecido inteiramente, mas se tornaram secundárias ou subordinadas às seguintes noções: a) de que os próprios documentos, em virtude da própria heterogeneidade dos 
registros, não são fontes de informação do passado, mas documentos de uma cultura; b) como são as perguntas da pesquisa que definem as fontes, não é possível decidir a priori onde começa e onde termina o documento.

É também por isto que a História precisa se aproximar dos paradigmas contemporâneos da Ciência. Precisamente para, tendo-os enquanto norte, não se deixar levar por uma das muitas ventanias pós-modernas. Neste sentido é que, na seção seguinte, apresento um diálogo entre a prática historiográfica por um lado e alguns aspectos do pensamento relativístico e quântico por outro.

\section{A História e os Paradigmas Relativísticos e Quânticos da Cientificidade}

Proponho três pontos de ruptura com a história anacrônica. Considerando-os como o mínimo de percepção e reação, constituem o núcleo de uma nova compreensão, indispensável à disciplina História para que esta possa, enfim, dialogar com os paradigmas atuais da cientificidade: a) Considerar possíveis influências vindas do futuro na produção do conhecimento do passado, isto é, admitir, por assim dizer, uma história assimétrica; b) Pensar a relação entre o sujeito e o objeto enquanto unidade e consequentemente especular a respeito de nossa contribuição, não apenas epistemológica, mas também ontológica, ou seja, na construção efetiva da realidade histórica; c) Entender que o passado é existente e mutante e, portanto, deve ser visto de maneira necessariamente probabilística.

\section{As Influências do Futuro e a História Assimétrica}

A primeira ruptura que a historiografia em seu diálogo com os paradigmas atuais da cientificidade deve apresentar é, correspondendo à nova perspectiva de causalidade envolvida, admitir a importância do futuro na produção do conhecimento histórico.

O enfoque que Quentin Skinner (1996, pp. 10 e 11) dá às fontes e questões relacionadas à teoria política, é visível em todas as outras áreas de investigação histórica, a socioeconômica, a cultural, etc. Segundo ele é a própria vida política que 
fornece os problemas para o teórico da política, forjando questões que se convertem nos tópicos a serem discutidos. Não que tais estruturas ideológicas sejam uma simples consequência de sua base social. Na realidade, deve-se também considerar o contexto intelectual em que foram concebidos os textos, ou seja, o das obras anteriores e suas heranças, igualmente o das produções da época do autor em estudo.

Em resumo, para Skinner, a produção de um teórico político nasce de sua análise pessoal a partir tanto das estruturas sociopolíticas de sua época quanto de uma determinada tradição e contemporaneidade bibliográficas. Isto é, naturalmente, verdade. O que, porém, Skinner não considerou e devia tê-lo feito são as influências do futuro, quero dizer, as possíveis influências das obras posteriores, bem como, ainda que em menor grau, das estruturas sociopolíticas futuras.

O princípio é o mesmo para todas as outras áreas de investigação: considerar e avaliar a influência que o futuro tem na construção do passado. Penso então haver uma distinção fundamental entre as influências de obras posteriores e de estruturas sociais futuras. São sempre imagens vagas. Porém, o pensamento posterior pode influenciar um teórico como um historiador de uma maneira mais direta, assumindo a forma de ideias transmitidas enquanto insights, ademais, neste caso temos um caminho de investigação melhor definido: o da posteridade de sua própria linha de estudo e das suas relações com as outras linhas. Já as estruturas sociais futuras chegariam ao historiador numa forma necessariamente imprecisa e fragmentada, enquanto meros traços que, assim, dificilmente seriam acolhidos por seu ego gerando considerações. Porém, mesmo fragmentos desconexos, quando repetidos com frequência, podem se tornar habituais e então assimiláveis pelo ego, constituindo prováveis considerações. Aqui, ao contrário, penso que o caminho de investigação se encontra ainda por construir.

Naturalmente que não se complexa algo (complexar algo é aumentar o número de suas relações) sem com isto criar problemas que, enquanto novos, necessitarão de tempo para serem resolvidos. Com possíveis influências vindas do futuro é inegável que a investigação histórica ficou mais complexa, o que fez surgir o problema da definição do caminho que nos permita estabelecer, em cada caso, o quanto estamos sendo influenciados por estruturas e processos sociais futuros e quais são exatamente essas influências, isto, porém, não deve nos intimidar. Que enorme complexação os Annales não trouxeram com suas novas fontes e novas áreas de estudo, quantos problemas não 
surgiram então sendo que, precisamos admitir, muitos deles não foram resolvidos até hoje. Notem que se isto tivesse intimidado as três gerações de annalistas, a história positivista ainda seria dominante.

Em virtude desta nova preocupação a qual não podemos fugir, cunhei o termo História Assimétrica, ou seja, a que considera que a prática historiográfica se encontra regida por uma causalidade de duas pontas. Notem que não está em discussão aqui a própria seta do tempo, apenas a do olhar do historiador. Ademais, não resta dúvida que o passado é a base de nossa atenção e preocupação. Porém, ao focar o passado, precisamos considerar que nossa investigação pode estar sendo influenciada também por ideias e imagens que, no entanto, nos chegam do futuro. Eis que a atitude seguinte será de cada historiador e dependendo também das especificidades de cada pesquisa. Pode-se então pensar que o mais correta seria sempre filtrar tais influências, mas não é absurdo supor que, ao contrário, ideias e mesmo estruturas futuras podem auxiliar na visão do passado.

Ainda que possam estar estranhando muito minha formulação, não há nada errado com ela. O ponto central de sua crítica, sei-o bem, é que não conseguem conceber um efeito anterior à causa. No entanto, um dos maiores físicos do século XX, Erwin Schrödinger (1977, p. 159-161), a partir do limite superior da Relatividade Especial ou Restrita de Albert Einstein, salienta, com a Noção de "Região de Simultaneidade Potencial", o fim da tirania do Cronos e a liberação da inquebrantável regra do antes e depois. ${ }^{1}$ Trata-se da razão teórica que embasa o dito. Também, o experimento, histórico na Mecânica Quântica, que faz uso de um interferômetro de Mach-Zehnder e é chamado de Escolha Demorada ou Retardada, demonstra na prática, abordando o tema do colapso de onda ${ }^{2}$ numa perspectiva também retroativa, a possibilidade de uma causação "marcha à ré". 3

Assim, efeitos podem perfeitamente anteceder suas causas. O que é já verdadeiro para os casos em que a disseminação dos efeitos ocorre pela via do espaço-tempo. Sendo que, no entanto, tudo fica bem mais fácil quando, ao contrário, tal disseminação ocorre por fora do espaço-tempo. Quero dizer, na via da não localidade quântica. ${ }^{4}$ Há um consenso relativo no sentido de que seja este o caso do colapso da função de onda. ${ }^{5}$ Também, é justamente o que se dá na minha proposta aqui de influências vindas do futuro, 
O meio não local serve de intermediação de ideias e imagens entre o futuro e o passado. Eis que tal determinação também é consistente com a experimentação. De fato, a correlação ou interconexão não local entre mentes é, hoje em dia, tida praticamente como fato científico na neurofisiologia e neuropsiquiatria quânticas, comprovada por diversos experimentos. Principalmente, os desenvolvidos por Jacob GrinbergZylberbaum et al (1994) e Peter Fenwick (1999). ${ }^{6}$ Como nesses experimentos os indivíduos foram colocados em gaiolas de Faraday, mas mesmo assim mantiveram a intercomunicação o tempo todo, não há de fato dúvida que o fizeram não localmente, pois o dispositivo em questão impede toda e qualquer transmissão de sinais eletromagnéticos, ou seja, locais, entre eles. Tais experimentos podem ser assim vistos como uma comprovação da comprovação da não localidade quântica. Quer dizer, comprovam as conclusões dos experimentos desenvolvidos pelas equipes de Aspect e de Gissin.

Assim não há nenhum problema de fato com o que eu estou dizendo e bem posso enunciar minha tese. Seu fulcro se encontra no fato de que ideias e imagens podem ser compartilhadas por mentes em estado de correlação ou interconexão no domínio não local, ${ }^{7}$ produzindo no domínio do espaço-tempo, num campo imperceptivo primeiro ("inconsciente coletivo"), ${ }^{8}$ num campo perceptivo depois (no pensamento), respectivamente, a partir de uma memória coletiva, experiências de criatividade.

Em outras palavras, além da interconexão menos indireta de ideias, os olhos de observadores futuros são, em certo sentido, nossos olhos igualmente, pois podemos observar traços do futuro através deles. A questão é, então, o quanto tudo isso nos influencia sem que percebamos, o quanto, consequentemente, altera nossas análises do passado. Vimos ser um problema real, já que embasado por princípios teóricos e dados experimentais bastante conclusivos. Não digo então que a probabilidade não seja baixa. Nos experimentos Grinberg-Zylberbaum e de Fenwick, como vimos, o resultado foi positivo em $70 \%$ dos casos, contudo nele os indivíduos procuraram desenvolver tal intercomunicação. Mas exatamente porque alcançaram um resultado tão satisfatório é fácil supor que, ao nível do inconsciente coletivo de Jung, haja ao menos uma probabilidade baixa de haver intercomunicação que, no entanto, pode ser ampliada mediante uma série de fatores como o potencial intercomunicante do estímulo envolvido ou alguma pré-disposição por parte do receptor. Portanto, a metodologia em 
História não pode simplesmente deixar de enfrentar o problema que implica em considerar tais influências. Sejam, em cada estudo particular, tidas então enquanto contaminações ou enquanto elementos inerentes à construção da História, deve-se, em todo caso, incluí-las sempre nas preocupações habituais que envolvem toda e qualquer pesquisa histórica.

\section{O Sujeito-Objeto e a Construção Ontológica da História}

Outro aspecto que uma, por assim dizer, História Relativístico-Quântica precisa encabeçar é o da contestação da dualidade entre sujeito e objeto. Com efeito, esta corresponde a mais uma determinação da Ciência Moderna: tal divisão é cartesiana. Na visão quântica, no entanto, numa linha que Schrödinger (1977, p. 138) chama de "escola predominante de pensamento na física quântica" e cujos protagonistas são Niels Bohr, Werner Heisenberg, Max Born e outros, a relação entre sujeito e objeto toma "novas cores". A ideia central, como salienta Schrödinger (1977, p. 138), é que não é possível se fazer nenhuma afirmação factual sobre dado objeto natural ou sistema físico sem entrar em contato com ele. Este contato é, então, visto como uma verdadeira interação física. Destarte, conclui Schrödinger (1977, p. 138), não é possível obter qualquer conhecimento sobre um objeto e, simultaneamente, deixá-lo estritamente isolado.

$\mathrm{Na}$ verdade, como afirma: as descobertas da física quântica nos levam a entender que "nunca observamos um objeto sem que ele seja modificado ou tingido por nossa própria atividade ao observá-lo" (SCHRÖDINGER,1977, p. 138).

Naturalmente que a observação transforma também o observador. A este título, cabe lembrar o famoso fragmento de Heráclito, em que este filósofo pré-socrático afirma que nenhum homem toma banho duas vezes no mesmo rio. ${ }^{9}$ Com efeito, tanto as águas são outras quanto o próprio homem é outro, tendo este sido renovado, pela observação e pela experiência, desde o primeiro banho.

Assim não faz mais qualquer sentido se falar em um sujeito e um objeto, mas, sim, num sujeito-objeto. Devemos colocar, no lugar da dualidade, uma unidade. Trata-se de uma interação profunda em que sujeito e objeto se desenvolvem mutuamente. 
As consequências na historiografia me parecem bastante evidentes. A História é uma construção. Ninguém mais duvida disto. Contudo, não apenas no sentido epistemológico, mas igualmente no ontológico.

Eis que, então, retornamos às influências do futuro, porém, num sentido todo novo. Não apenas tomamos conhecimento do futuro pela via não local, mas, por esta mesma via, ajudamos a construir ontologicamente, quer dizer, efetivamente, o passado. Não apenas nós historiadores, mas também os diletantes. Com efeito, sob o ponto de vista físico, a influência provocada tanto por historiadores quanto por diletantes é, $a$ priori, a mesma.

Tanto construímos quanto somos construídos, mas gostaria aqui de realçar o papel de historiadores e diletantes como agentes ontológicos da História. Notem que quando Werner Heisenberg sugeriu o Distúrbio Interacional, ele tinha em mente sobretudo o universo das partículas como, por exemplo, os fótons do raio de luz alterando a posição do elétron que se estava medindo. 10 No universo macroscópico, no entanto, é perfeitamente possível se pensar num efeito acumulativo. A ação de um único historiador ou diletante é de fato desprezível, mas para sabermos até que ponto interferimos, por exemplo, na Revolução Francesa ou na Guerra dos Cem Anos, devemos considerar o papel de todos os historiadores e diletantes que as estudaram, as estudam e as estudarão, pois, como veremos um pouco mais adiante, estão as estudando agora.

Neste ponto, no entanto, é preciso estabelecer uma distinção fundamental, sem a qual estaremos sujeitos a grandes confusões. Notem que, até este momento, não falei que o passado muda. As influências de historiadores e diletantes ajudam a construir o passado de uma determinada maneira, com determinada forma e características, não parecendo que, após sua constituição, impõem-lhe qualquer mudança. É exatamente por isto que tais influências são encontradas nas próprias fontes.

Estas constituem assim, além do núcleo de conteúdo original, a média possível de todas as influências diferentes e mesmo contraditórias que somos capazes de provocar, sendo assim constituída pela composição e combinação, mais coerente ou menos coerente conforme o caso, de todas elas. ${ }^{11}$

Trabalho, sim, com a perspectiva de um passado mutante como, aliás, já o disse, mas considero-o submetido a uma mudança exclusivamente ad-intra. Uma que ocorre em virtude da natureza do próprio movimento da história sincronicamente no tempo, portanto, regida pelo funcionamento de um "motor" intrínseco ao passado.

Na realidade, o limite aqui não é tão preciso. A Natureza não se reduz ao Método. Trata-se de uma fronteira bastante nebulosa. É preciso entender que o "motor" que impulsiona a mudança do passado faz o mesmo por todo o tecido do espaço-tempo. Assim, o 
futuro se encontra também submetido a um processo de mudança. Vejam que ainda que se admita que o passado conforme se encontra registrado nas fontes inclui, numa média de coerência variável, todas as influências futuras até a consumação do espaço-tempo, uma vez que o futuro é também mutante, como se pode estar de fato certo disto? Convém, no entanto, manter tal princípio enquanto uma convenção, porque senão, diante da confusão que seria engendrada, corre-se o risco de desestruturação da metodologia que proponho.

O que não é, como pode parecer, uma insuficiência específica da metodologia proposta. Trata-se, efetivamente, da incompleteza inerente a toda e qualquer metodologia e inerente à Ciência como um todo. Com efeito, a Ciência, entendida enquanto conhecimento humano, pela própria limitação da abertura da mente da nossa espécie, não pode tudo evidentemente. Antes, é capaz de compreender a realidade apenas numa limitação correlativa.

Mas há ainda outro problema. Vimos que nossas influências ontológicas na História estão já nas fontes, penso, porém, ser bastante difícil mapeá-las. Contudo, é justamente porque nas fontes tais influências se confundem com tudo mais, que o recurso à intuição deve estar sempre presente. A intuição já vem sendo empregada na construção epistemológica da História, pois tal recurso, dentre outros, se tornou viável justamente a partir da negação da neutralidade e objetividade positivistas; deve, no entanto, sê-lo também na evidenciação e identificação de nossa interferência ontológica. Não há, de fato, nenhum senão a priori, com a própria intuição, mas apenas $a$ posteriori, em se deixar levar pela intuição. Cabe, pois, permanecer o tempo todo no comando, usar o senso lógico e a base teórica que já dispomos para questionar a intuição a cada passo do pensamento.

Como se pode ver, problemas não faltam. Mas, por um lado, nunca disse que a prática historiográfica atual, no que pese suas próprias dificuldades, não é, no entanto, confortável em comparação ao desafio que implica uma História Relativístico-Quântica. Digo, isto sim, que, diferente da historiografia positivista em sua própria época, a empregada hoje em dia é anacrônica, pois, desconhecendo as evoluções (evolução é complexação) da Ciência no século $\mathrm{XX}$, se encontra aquém dos paradigmas da cientificidade então vigentes. Digo também que é perigosa, pois, não trilhando o caminho da cientificidade atual, corre o sério risco de perder toda sua cientificidade, vindo mesmo a contestar seu papel de produtora de verdade/conhecimento como vimos. 
Por outro, cabe simplesmente reconhecer que, como dito acima, não só a História, mas toda a Ciência, enquanto produção humana, é capaz de produzir apenas um conhecimento limitado, e, desta forma, ser possuidora de grande margem de erro, estando assim, aliás, de acordo com a visão da incerteza quântica.

A tal propósito, não se pode confundir um princípio específico de incerteza, como foi o desenvolvido por Heisenberg, com a incerteza geral que tal princípio instaurou no pensamento quântico. O Princípio de Incerteza, como observa Osvaldo Pessoa Junior (2006, p.77), se aplica a grandezas incompatíveis, representadas por operadores não comutáveis como posição e momento, exprimindo o fato de que uma maior previsibilidade nos resultados da medição de um dos observáveis implica numa diminuição necessária na previsibilidade do outro. Contudo, como explica o físico americano Brian Greene (2004, p. 123), a incerteza faz parte da própria estrutura ondulatória da Mecânica Quântica, existindo ainda que não façamos nenhuma medição. Como os objetos, sejam clássicos ou quânticos, independente de serem vistos como epistemes ou como entidades, são a priori ondas e ondas se espalham, há obviamente uma enorme incerteza a respeito de sua posição.

Contudo, ainda que na Mecânica Quântica seja sobretudo essa a preocupação, tais ondas não representam apenas posições, mas toda e qualquer variável, pois são ondas de possibilidades de praticamente tudo. Notem que isto não se resolve então na indeterminação probabilística, constituindo um problema para além dela. Naturalmente que podem haver possibilidades que desconhemos inteiramente, especialmente a determinação das probabilidades das possibilidades tem por base parâmetros sempre sujeitos a flutuações quânticas imprevisíveis (pois, como explicarei na seção seguinte, não apenas o futuro mas igualmente o passado estão continuamente mudando), sendo exatamente por isso que há, em todas as ciências, uma incerteza essencial inerente a todas as ideias que formulamos sobre todas as coisas.

\section{O Passado Existente e Mutante e a História Probabilística}

Eis que, fechando esta breve análise, gostaria de tratar de mais um aspecto crucial a ser abordado numa discussão e prática historiográficas que, por dialogar com os 
paradigmas atuais da cientificidade, pode ser chamada de História RelativísticoQuântica: a mudança do passado.

A razão que comumente nos leva a negar o movimento do passado consiste na ideia de que existe um passado efetivo e que, sendo assim, já passou, de forma que não pode estar ainda mudando; ao contrário, ele está dado, está já dado. Mas isto é só Newton falando. Einstein, ao contrário, disse uma vez que "a distinção entre o passado, o presente e o futuro é apenas uma ilusão, ainda que persistente" (EINSTEIN apud GREENE, 2005, p. 168).

O que Einstein queria dizer é que o fluxo do tempo (ou seja, o princípio de base da distinção entre passado, presente e futuro) é apenas fruto de uma ilusão dada pela incapacidade dos nossos sentidos lidarem com o tempo, com que o tempo realmente é.

De fato, como salienta Brian Greene (2005, p. 168), numa visão einsteiniana o único lugar em que a distinção entre passado, presente e futuro está presente é a mente humana ou, da mesma maneira, a única coisa real aqui é a totalidade do espaço-tempo. ${ }^{12}$ Isto porque, como Greene nos explica (2005, p. 168), de acordo com a Relatividade Especial ou Restrita, da mesma forma como podemos conceber a totalidade do espaço como algo que realmente está presente, que realmente existe, também deveríamos conceber a totalidade do tempo como algo que realmente está presente, que realmente existe. Definitivamente, não há fluxo no tempo.

Consequentemente, não pode mesmo haver mais nenhuma dúvida: o "passado" não passou, ele existe em sua própria região do espaço-tempo.

Naturalmente que o rompimento com a visão científica colada ao "bom senso" da percepção diretamente sensível, isto é, o rompimento com a física newtoniana, ao mostrar o erro que encerrava a perspectiva de um passado efetivo e que já passou, permite se especular se o passado, além de existente, é mutante. Com efeito, se o passado existe simplesmente, ele se encontra em processo, por que não poderia então estar mudando?

No entanto, isto não resolve todo o problema. Dizer, por exemplo, que eu estava reunido com minha família na noite de Natal de 2019, significa dizer que eu estou, que eu ainda estou reunido com eles, uma vez que isto ocorre em uma localização do espaço-tempo e este não tem fluxo. Mas não significa dizer que eu lá estou diferente- 
mente. Este é o problema. A Física Relativística, por ela mesma, não comprova a minha perspectiva de mudança do passado.

Para ser bastante sincero, a relatividade em si contraria minha perspectiva. Como nos explica outro físico americano, Michio Kaku (2000, pp. 259 a 262), segundo a noção de linha de mundo de Albert Einstein, ${ }^{13}$ como esta não pode ser cortada, ${ }^{14}$ não é possível o passado mudar na relatividade: mesmo que pudéssemos fisicamente voltar no tempo e com isto nossa linha de mundo recuasse, ela simplesmente formaria um laço e assim realizaria o que já é sabido.

Contudo, se algo que ainda está em processo não pode mudar é porque está obrigado a ser de tal jeito. Mas admitir isto é por demais incômodo! Afinal, é o mesmo que se dizer que a revolução que a Ciência passou na primeira metade do século XX nos levou a confirmar aquilo os místicos já sabiam desde sempre: que vivemos sob o Império do Destino.

Recuso-me a aceitar isto! Com efeito, a ideia de Einstein foi mantida na Mecânica Quântica porque tal teoria trabalha com o pressuposto que a passagem de potência a ato, o colapso da função de onda, é definitivo e, portanto, não só o passado, mas o tempo como um todo está congelado.

No Postulado de Projeção, como novamente aponta Pessoa Júnior (2006, pp. 59 e 60), John Von Neumann descreve na medição uma evolução de estados que se dá não linearmente, praticamente instantânea e descontínua, irreversível e não determinista. Notem que a irreversibilidade do colapso parece ser contrariada pela escolha retardada do experimento proposto por John Wheeler, ${ }^{15}$ mas mesmo assim fez carreira triunfal. Criou-se em consequência a convicção de que, se o tempo pode ser comparado com um rio, uma vez que ele não passa e tanto as coisas quanto os eventos (todos os atos) nele presentes são irreversíveis, ele é, no entanto, um rio congelado.

Mas tal consenso esconde mal uma ambiguidade, mesmo uma contradição. Aquela dada entre a perspectiva de um passado existente, que assim implica num sistema que evolui também sincronicamente; e a afirmação que ele não muda, portanto, estabelecido exclusivamente por determinada diacronicidade.

Com efeito, se nos deixamos levar pela perspectiva de Von Neumann, ainda que o passado siga existindo, uma vez que ele se encontra atado ao que foi determinado por 
séries de colapsos invariáveis, está estabelecido definitivamente em tal diacronicidade e, portanto, condenado a ser necessariamente o mesmo. Se o passado é sempre o mesmo, uma vez que o presente e consequentemente o futuro dependem casualmente do passado, são também sempre os mesmos. O tempo, portanto, está congelado, quer dizer, ele com tudo o que existe nele. Porém dizer isto é o mesmo que afirmar que o tempo e a história são comandados pelo Destino. Se os físicos podem conviver com essa; eu não!

No entanto, se o colapso for reversível e, portanto, sua determinação não for definitiva, abre-se uma oportunidade à mudança. Concluímos que foi assim, mas ainda pode ser diferente, isto porque a superposição quântica retornou em meio à sincronicidade do tempo sem fluxo sendo, no entanto, submetida agora a um colapso diferente. Por que não? Nesta toada, toda uma série de colapsos novos, uma diacronicidade nova portanto, poderia então se formar. É então bastante coerente se pensar que mais e mais diacronicidades surgiriam, pois, afinal, o tempo continua não passando e assim a sincronicidade persiste mudando. Eis que com isto sincronicidade e diacronicidade não estariam mais em duelo, antes cooperariam na mudança inerente à noção inambígua e inequívoca de não fluxo do tempo.

Nesta perspectiva, ou a História assume o processo de mudança do passado ou é essencialmente incompleta. Notem que a História é incompleta necessariamente. Primeiro porque, obviamente, as fontes não registram a gama completa dos acontecimentos e processos envolvidos, ainda menos as representações a eles relativas. Porém, mesmo que registrassem, não poderiam ser todos eles objetos para a História, já que considerá-los seria cair num empirismo absoluto (num verdadeiro "lixão de particulares" tal qual o do memorioso Funes do conto de Jorge Luís Borges), de todo não analisável. Segundo porque nossa investigação é feita na medida de nossa capacidade de pensamento, ou seja, apenas representativamente e, assim, redutiva em relação à própria realidade histórica. Contudo, não deve a História ser uma construção epistemológica dada a partir de uma realidade determinística, quer dizer, definida e definitiva, se, afinal, o Destino não tendo vez no não fluxo, o passado se apresenta indeterministamente, enquanto um quadro de realidades possíveis. ${ }^{16}$

Precisamos, pois, introduzir as possibilidades na História. A antiga ideia, mas ainda advertência e assim prescrição ao historiador, de que a História não é feita de ses, ou seja, que devemos estar atentos apenas ao que se encontra de alguma forma 
registrado nas fontes, vem, felizmente, perdendo lugar hoje em dia. Numa historiografia de ponta, já se admite abertamente o recurso às possibilidades. Um bom exemplo aqui é o do Apêndice - Provas e Possibilidades (Posfácio a Natalie Zemon Davis, O Retorno de Martin Guerre), apresentado em O Fio e os Rastros: Verdadeiro, Falso e Fictício (2007) de Carlo Ginzburg. Contudo, não podemos apenas empregar as possibilidades para resolver as ambiguidades e preencher as lacunas das fontes como então deseja Ginzburg. Elas, como vimos na seção anterior, são imprescindíveis às considerações que permitem a construção da história dos indivíduos ou Nanohistória. Também, se o passado é mutável, devemos naturalmente compreendê-lo enquanto tal, tornando assim os ses o elemento norteador da História. Alcançamos enfim a percepção probabilística da verdade, um dos maiores avanços da Mecânica Quântica no campo do conhecimento.

Posso então sugerir a construção do texto historiográfico em duas etapas. O primeiro passo é o da produção do Texto-Base. Mas o que quero dizer com Texto-Base? Trata-se, como o próprio termo indica, de uma análise prévia, uma abordagem interpretativa elaborada diretamente a partir das fontes disponíveis que, no entanto, constitui apenas uma primeira composição.

Tal texto é somente introdutório porque não mais que um recorte de algo que está em movimento, um instantâneo do processo de mudança. Portanto, a partir do texto inicial, o Texto-Base, devemos, num processo que envolve tanto intuição quanto investigação rigorosa, especular as diversas possibilidades envolvidas, e por fim avaliar a probabilidade de cada possibilidade. Construímos então não todo o movimento, não o processo inteiro de mudança do passado, evidente que não, mas ao menos uma parte significativa dele. Em Ciência é preciso sempre ser humilde! Em todo caso, dessa forma o "filme" substitui a "foto". A Análise Quântica toma o lugar do Texto-Base.

Este é de fato o único caminho que é possível percorrer para se compreender algo da mudança que está para além das fontes. Seu ponto de partida, no entanto, encontra-se na possibilidade levantada na interpretação das fontes. A partir desta, especulase/perscruta-se as demais. Todas, vistas probabilisticamente.

Bem cabe um exemplo. Se, estudando o pensamento político de Dante Alighieri (início do século XIV) a partir das fontes disponíveis (O Convivio, a Commedia e a De Monarchia), chega-se a conclusão que o autor desenvolveu uma concepção, revolucionária na história do pensamento cristão, de duas beatitudes, isto significa tão 
somente que esta é, segundo a visão do historiador da Filosofia que as analisou, ${ }^{17}$ a possibilidade quântica colapsada de que temos o registro. De fato, nada além de um recorte ou instantâneo de um movimento, de um processo de mudança. Mas o que diria Dante a este respeito agora? Ou seja, no nosso agora do século XXI, que para Dante corresponde ao seu agora do século XIV. Ele continua defendendo duas beatitudes ou mudou de convicção? Não é possível ter certeza alguma. O que podemos fazer é apenas especular, a partir da possibilidade colapsada que foi levantada nas fontes, gamas ou linhas de possibilidades, e, então, procurar determinar a probabilidade de cada possibilidade.

Procede-se da seguinte forma. A possibilidade colapsada nas fontes é, segundo nossa interpretação, duas beatitudes. Baseada nesta, especula-se uma gama ou linha de possibilidades, algo como: nenhuma beatitude, uma beatitude, ainda duas beatitudes, três beatitudes, mais de três beatitudes. Esta é a gama ou linha central que, então, abre caminho para gamas ou linhas secundárias, terciárias, quaternárias, etc, até um limite especulativo dado no método. Ou seja, consiste em vasculhar as possibilidades dentro das possibilidades: as subpossibilidades. Só por exemplo, dentro da possibilidade uma beatitude, duas alternativas: uma beatitude e um fim último ou uma beatitude e fins antecedentes. Seguindo o exemplo, dentro da subpossibilidade uma beatitude e um fim último, mais três alternativas: uma beatitude e um fim último guiados, respectivamente, por papa e imperador ou uma beatitude e um fim último guiados ambos pelo imperador ou, ainda, uma beatitude e um fim último guiados ambos pelo papa. ${ }^{18} \mathrm{E}$ se faz o mesmo para as demais possibilidades, da gama ou linha central que especulamos previamente. Determinamos assim todas as subpossibilidades quânticas. Investiga-se, em seguida, todas as possibilidades com todas suas subpossibilidades para identificar a probabilidade de cada uma. Fecha-se a Análise Quântica com um quadro que apresenta a hierarquização probabilística de todas as possibilidades e de todas suas respectivas subpossibilidades.

Com tudo isso, o Texto-Base é apenas uma interpretação preliminar, feito para ser substituído pela Análise Quântica, o passo definitivo sem o qual a produção historiográfica, volto a o dizer, é essencialmente incompleta. Isto não significa que, no entanto, devemos relegar o Texto-Base a um patamar inferior. Seria um grave erro metodológico! Ficaríamos sem o suporte necessário, a "âncora" em que basear nossa análise das possibilidades. Afinal, como "conhecer o vôo" sem antes estudar devidamente a "estrutura da asa"? 
O trabalho é de fato um tanto exaustivo, mas, uma vez feita a Análise Quântica, temos algo do processo de mudança. Não cabe, então, lamentar não termos todo ele. Ora, nosso "pássaro" é migrante. Caso estejamos em local privilegiado, podemos vê-lo decolar e cruzar o céu, mas só acompanhamos seu voo até o horizonte. Além deste limite, nossos olhos, sejam de historiadores, físicos, filósofos ou outros cientistas, ou ainda não cientistas, enquanto meros olhos humanos, são inúteis. Mas será que, ao menos neste curto trecho de céu que nossa visão alcança, conseguimos dominar todas as nuanças do voo? Certamente também não! Dizia Albert Einstein (1994, p.229): "a razão é evidentemente débil quando confrontada com sua infindável missão".

\section{Conclusão}

Sei que minhas preocupações metodológicas podem ser pouco digeríveis, talvez mesmo intragáveis, para os colegas historiadores. Como nossa Ciência se desenvolveu, ao longo do século $\mathrm{XX}$, dialogando apenas com seus vizinhos, particularmente com as Ciências Sociais, que não fizeram diferente, o risco de não vir a ser entendido é muito grande. Mediante a interdisciplinaridade da História não ter chegado jamais ao centro das discussões, ocorridas estas na Física, falar em influências do futuro e mudança do passado pode mesmo provocar risos. Contudo, não se pode continuar evoluindo em "pote fechado" para sempre. Mais cedo ou mais tarde a História, bem como as demais humanidades, vão ter que chegar ao século XXI, em que não são mais Newton e Descartes "que dão as cartas". Por que não agora?

Para os que então se sentem desconfortados em aplicar, numa ciência humana como é a História, paradigmas desenvolvidos numa "ciência da Natureza" como é a Física, notem que não estou falando em aceitação pura e simples dos princípios dados pelos físicos, apenas em diálogo com eles. Pôde-se ver como questiono Einstein e toda a Mecânica Quântica a respeito do seu passado existente, todavia, não mutante.

Isto sem falar que é urgente silenciar vozes dissonantes para com a Ciência que, inegavelmente, existem no meio historiográfico. A morte do positivismo permitiu a compreensão da história como construção dos historiadores num sentido epistemológico, porém, tal avanço, em uma "carroça de condutor incerto", que bem é o caso da historiografia atual, pode bem nos levar "ao fundo do poço". Falo da 
constituição de uma prática historiográfica que, tendo a "âncora" das fontes sido abandonada, não passaria de um pensamento ficcional. O risco é real! Não é atoa que, em meio à produção em teoria e metodologia histórica, volta e meia se recupera o tema da aproximação entre a História e Literatura.

Sustento esta afirmativa a partir das observações do historiador José D'Assunção Barros. Como salienta (2020, p.20), os historiadores da Terceira Geração dos Annales já não aceitavam ou ao menos não eram muito entusiastas da ideia de cientificidade da História. Alguns deles, como Paul Veyne, Georges Duby e François Furet, desde as últimas décadas do século XX, vêm mesmo questionando tanto as metodologias seriais quanto a importância de se vincar o discurso da cientificidade enquanto carro-chefe para se legitimar os Annales.

Paul Veyne parece ser o precursor da nova concepção. Novamente segundo Barros (2020, p.22), no livro Como se Escreve a História, de 1971, Veyne conduz a discussão sobre a relativização do "tempo histórico" e da obra historiográfica ao extremo. A ideia central é que o historiador se encontra livre para lidar com os fatos conhecidos e com as fontes que utiliza como materiais a fim de que possa utilizar seus próprios critérios para compor o que chama de uma intriga. Os fatos, discursos e fragmentos que lhe chegam do passado são selecionados, adaptados, conectados, ressignificados de acordo com os interesses da intriga que o historiador está construindo. O historiador procura assim compreender as intrigas humanas, mas não intrigas de processos que se deram no vivido, na realidade histórica; antes, embora comportem veracidade e se baseiem em materiais concretos que chegam ao presente, tais intrigas são produto de um esforço criativo da singularidade do próprio historiador. É de fato como sublinha Barros: "Vista desta maneira, a história explica enquanto narra, mas a explicação não é científica” (2020, p. 22).

Não mesmo, é literária ao invés de científica. O que, aliás, é ainda mais evidente em Georges Duby. Ainda segundo Barros (2020, pp. 20 e 21), Duby, em sua produção a partir de 1980, fala abertamente do papel da imaginação na escrita historiográfica, substituindo a antiga ideia do Passado construído enquanto uma "Problematização do Presente" pela do Passado construído enquanto uma "Representação do Presente". Representação sedutora, que parece dialogar não só com a literatura, mas também com a 
arte e o cinema, evocando não somente o Imaginário, mas também a Imaginação, inclusive no sentido de utilizá-la para preencher as lacunas das fontes.

Eis que, para o próprio Barros (2020, p.20), tal virada de perspectiva dos Annales se explica pelo fato de que a Nova História, na altura da Terceira Geração, já tinha tanto conquistado a mídia quanto se tornado um sucesso editorial, de forma que vai então procurar atender aos apelos desta mídia e do público ampliado de história, procurando construir textos sedutores, envolventes, prazerosos, em resumo, interessantes tanto para a crítica midiática quanto para a massa de seus leitores. Contudo, é indiscutivelmente um sinal do tempo em que vivemos. As opiniões de Paul Veyne e Georges Duby não seriam possíveis se então uma "ventania" pós-moderna não tivesse atingido os Annales.

Com efeito, a ideia de uma história-literatura seria bastante ingênua e, portanto, nenhum historiador de peso ousaria defendê-la, se, tendo nossos pés firmados na Ciência, soubéssemos sem rasgo de dúvida que nosso objetivo é a de criação de conhecimento ao invés de produção de beleza. Não que o texto historiográfico não possa ser tão belo quanto o literário, que deva mesmo sê-lo, mas que a beleza não é seu fim, ou seja, nele é apenas contingente.

\section{Referências}

ARIÈS, Philippe. O Tempo da História. Rio de Janeiro: Francisco Alves, 1989.

BARROS, José d'Assunção. Será a História uma Ciência: Um Panorama de Posições Historiográficas. In: Inter-Legere: Revista da Pós-Graduação em Ciências Sociais da UFRN. Vol 3, n. 27, jan./abr. de 2020.

Disponível em: https://periodicos.ufrn.br/interlegere/article/view/18662/12634

BURKE, Peter. Abertura: A Nova História, seu Passado e seu Futuro. In: BURKE, Peter (org.) A Escrita da História: Novas Perspectivas. São Paulo: Unesp, 1992.

CARDOSO, Ciro F. S. Uma Introdução à História. São Paulo: Brasiliense, 1981.

CHARTIER. Roger. A História Cultural entre Práticas e Representações. Rio de Janeiro: Bertrand Brasil, 1990. 
EINSTEIN, Albert. Escritos da Maturidade (Ciência, Religião, Racismo, Educação, Relações Sociais). Rio de Janeiro: Nova Fronteira, 1994.

GEERTZ, Clifford. A Interpretação das Culturas. Rio de Janeiro: LTC, 1989.

GINZBURG, Carlo. O Fio e os Rastros: Verdadeiro, Falso, Fictício. São Paulo: Companhia das Letras, 2007.

GREENE, Brian. O Tecido do Cosmo. O Espaço, o Tempo e a Textura da Realidade. São Paulo: Companhia das Letras, 2005.

KAKU, Michio. Hiperespaço: Uma Odisséia Científica através de Universos Paralelos, Empenamentos do Tempo e a Décima Dimensão. Rio de Janeiro: Rocco, 2000.

KOYRÉ, Alexandre. Estudos de História do Pensamento Científico. Rio de Janeiro: Forense Universitária, 1991.

OS PENSADORES. Heráclito de Éfeso: B - Fragmentos. In: Os Pré-Socráticos: Fragmentos, Doxografia e Comentários. Tradução de José Cavalcante de Souza, São Paulo: Nova Cultural, 1991.

PESSOA JUNIOR, Osvaldo. Conceitos de Física Quântica. Vol. I. São Paulo: Editora Livraria da Física, 2006.

REALE, Giovanni; ANTISERI, Dario. História da Filosofia. Vol. III: Do Romantismo até Nossos Dias. São Paulo: Paulus, 2005.

SALIBA, Elias Thomé. Aventuras Modernas e Desventuras Pós-Modernas In: PINSKY, Carla Bassanezi; LUCA, Tania Regina de (orgs.). O Historiador e suas Fontes. São Paulo: Contexto, 2013.

SCHAFF, Adam. História e Verdade. São Paulo: Martins Fontes, 1991.

SCHRÖDINGER, Erwin. Mente e Matéria. As Conferências de Tarner. In: SCHRÖDINGER, Erwin. O Que é Vida? (O Aspecto Físico da Célula Viva). Seguido de Mente e Matéria e Fragmentos Autobiográficos. São Paulo: Unesp, 1977.

SKINNER, Quentin. As Fundações do Pensamento Político Moderno. São Paulo: Companhia das Letras, 1996. 


\title{
TÔRRES, Moisés Romanazzi. Dante e o Princípio das Duas Beatitudes (Texto-
}

\author{
Base de Comentário à Filosofia Política de Dante Alighieri). São Paulo: Nelpa, 2014.
}

\footnotetext{
${ }^{1}$ Como explica Schrödinger (1977, pp. 160 e 161), a noção de antes e depois reside na relação de causa e efeito. Sabemos ou pelo menos formamos a ideia que um evento $A$ pode causar ou mesmo modificar um outro evento $B$, de tal forma que se $A$ não ocorresse, então $B$ não ocorreria, pelo menos não na forma modificada. Porém, dispomos da evidência observacional e experimental que os efeitos não se disseminam com uma velocidade arbitrariamente alta. Que há um limite superior ( $c t$ ) que, incidentalmente, é a velocidade da luz no espaço "vazio", no "vácuo". Consideremos então um evento $A$ e, em algum momento posterior, um evento $B$ fora da esfera de raio $c t$ em volta de $A$. Logo, $B$ não pode exibir qualquer vestígio de $A$; nem, é evidente, $A$ de $B$. Portanto, o critério falha, pois, sendo $B$ posterior, deveria poder exibir algum vestígio de $A$. Mas se supuséssemos ainda, em um momento anterior (através $t$ ), um evento $B$ ' fora daquela mesma esfera. Neste caso, da mesma forma que antes, nenhum vestígio de $B$ ' pode ter atingido $A$ (e, lógico, nenhum vestígio de $A$ pode ser exibido em $B^{\prime}$ ). Assim, em ambos os casos existe a mesma relação de não interferência mútua. Não existe diferença conceitual entre as classes $B$ e $B^{\prime}$ com respeito a sua relação causa-efeito com $A$. Assim, caso desejamos fazer dessa relação a base do antes e depois, então $B$ e $B$ ' formarão uma classe de eventos que não é nem anterior nem posterior a $A$. A região do espaço-tempo ocupada por essa classe é chamada de região de simultaneidade potencial (com respeito ao evento $A$ ). Emprega-se tal expressão porque é sempre possível adotar uma estrutura de espaço-tempo que torne $A$ simultâneo de um $B$ ou $B$ ' particular selecionado.

2 A noção, central na Mecânica Quântica, é a de redução da função de onda, esta consiste na transformação de uma onda de possibilidades espalhada num pacote bastante conciso que assim se assemelha a uma partícula (da Física Clássica), sendo que, como o processo implica no estabelecimento de uma definição, entende-se, via de regra, que corresponde a passagem da potência ao ato. Contudo, é preciso saber que os ortodoxos da Escola de Copenhagen consideram a onda de possibilidades tão somente como um episteme e, portanto, a redução da função de onda não é, como salientam, um processo real, mas uma mudança de percepção, de entendimento, ou seja, afeta apenas a informação que temos a respeito do objeto. É apenas na Interpretação Ondulatória, enfoque ao qual adiro, que a onda de possibilidades corresponde a uma entidade e, portanto, sua redução, então chamada colapso, corresponde a uma mudança real, de fato a transição de um objeto potencial a um objeto atualizado.

${ }^{3}$ Tal experimento foi sugerido pelo físico quântico americano John Wheeler. Nele, emprega-se enquanto aparelho um interferômetro de Max-Zehnder. Portanto, o objetivo é dividir um pulso monofotônico em dois, um transmitido (componente $A$ ) e o outro refletido (componente $B$ ), de igual intensidade por meio de um semi-espelho $\left(S_{l}\right)$. Depois, os dois componentes são reunidos em um ponto de cruzamento $P$, usando espelhos comuns $\left(E_{l} \mathrm{e} E_{2}\right)$. Se, então, colocarmos detectores (fotomultiplicadores) além do ponto $P\left(F_{1}\right.$ na sequência do caminho $B$ e $F_{2}$ na sequência do caminho $A$ ), cada um irá detectar fótons (um a cada 30 em média) em 50\% das vezes. Como cada evento de detecção define um dos dois caminhos para o fóton detectado, temos um fenômeno corpuscular. Porém, para termos um fenômeno ondulatório ao invés de corpuscular, basta colocarmos um segundo semi-espelho $\left(S_{2}\right)$ em $P$. Pois, caso um defasador $H$ seja também colocado no caminho de $A$, forçando, pela variação de fase que provoca neste componente, a interação construtiva deste lado do interferômetro, apenas $D_{2}$ irá responder, ou seja, em $100 \%$ das vezes. $\mathrm{O}$ que, então, fez Wheeler em seu experimento-de-pensamento foi introduzir a seguinte variante. Bem, fótons levam alguns nanossegundos para ir de $S_{l}$ a $S_{2}$. Suponhamos então que o experimentalista venha a inserir o segundo semi-espelho, dentro desse intervalo de tempo, após a frente já ter se dividido no primeiro semi-espelho. O que iria acontecer? É natural se pensar que, como os fótons já terão começado a percorrer o caminho designado, irão continuar a exibir um fenômeno corpuscular, porém, não é isto que acontece. Eles respondem à escolha retardada de inserir o segundo semi-espelho em $P$, exibindo um fenômeno ondulatório, ou seja, viajando pelos dois caminhos. Mas se estivéssemos no meio do experimento ondulatório e os dois semi-espelhos $S_{1}$ e $S_{2}$ já estivessem em suas posições, e, então, fosse feita a escolha de remover $S_{2}$ no último instante, o que aconteceria? Novamente os fótons respondem a escolha retardada e, assim, exibem um fenômeno corpuscular, pois percorrem um dos dois caminhos. Ou seja, este experimento demonstra, bastante bem, que é nossa percepção sensorial que estava errada.
} 


\begin{abstract}
${ }^{4}$ A visão da Mecânica Quântica não é clara a este respeito. Mas o que poderia de fato ser a não localidade senão uma região física sem espaço e sem tempo, ao menos sem espaço e tempo efetivos e manifestados, o que permitiria comunicações superluminosas e mesmo a troca instantânea de dados, quer dizer, tudo isso ocorreria sem violar o limite superior da Relatividade Restrita (como visto, dada pela velocidade constante da luz no "vácuo") já que este se encontra determinado necessariamente por uma condição de localidade. Cabe salientar que tal proposta se revelou consistente com a experimentação. De fato, a partir dos experimentos de Alain Aspect et al (1982) em Orsay (França) e Nicolas Gissin et al (1997) na Suíça, consta que foi possível comprovar o princípio da não localidade quântica.

${ }^{5}$ Com efeito, o colapso ocorre instantaneamente à inserção de um medidor em todo e qualquer experimento quântico em que se deseja produzir um fenômeno corpuscular, o que não seria possível se o efeito provocado por esta inserção seguisse localmente já que então mais rápido que o mais rápido existente, ou seja, mais rápido que a luz.

${ }^{6} \mathrm{O}$ experimento de Grinberg-Zylberbaum et al consiste em fazer com que dois indivíduos meditem juntos a fim de estabelecerem uma comunicação direta. Depois de 20 minutos, eles são fisicamente separados e colocados em gaiolas de Faraday (o que, como sabido, impossibilita a transmissão de sinais eletromagnéticos). Em seguida, cada cérebro é ligado a um eletroencefalógrafo. Mostra-se então a um dos dois indivíduos uma série de flashes de luz, produzindo uma atividade cerebral que é registrada na máquina de EEG. Deste registro, se obtém com o auxílio de um computador, após retirar o ruído cerebral, um potencial evocado. Eis que os resultados foram então surpreendentes. Viu-se que, de alguma maneira, em cerca de $70 \%$ das vezes, o potencial evocado foi imediatamente transferido para o cérebro do outro indivíduo, pois, mesmo este não tendo sido submetido aos flashes, seu EGG (tomado ao mesmo tempo em que o outro EGG), após ter sido retirado o ruído cerebral, apresentava um potencial similar em fase e força ao potencial evocado no primeiro indivíduo. Já o experimento de Fenwick é exatamente o mesmo com a variante de utilizar estímulos sonoros ao invés de visuais.

${ }^{7}$ Penso que tal correlação pode ser estabelecida mediante estímulos diversos. Eu mesmo posso estar sendo influenciado neste exato momento porque alguém que no futuro está lendo este artigo e, então, pensando a respeito dele.

8 Trata-se de uma noção central da teoria psicológica do suíço Carl Gustav Jung. O "inconsciente coletivo", que para Jung representa a camada mais profunda da psiquê, não é formado a partir de experiências individuais como o "inconsciente pessoal" de Freud, ainda que necessite de tais experiências para sua manifestação. Seus traços funcionais foram chamados por Jung de arquétipos, significando que não são observáveis neles mesmos, mas apenas através das imagens que eles proporcionam. Contudo, o "inconsciente coletivo" funciona enquanto uma memória comum de todos os homens, pois retém informações arquetípicas e impessoais, sendo que seus conteúdos podem então ser intercomunicados entre os indivíduos ao longo do processo de desenvolvimento da vida. Para um conhecimento aprofundado recomendo as seguintes leituras:
\end{abstract}

JUNG, Carl Gustav. Os Arquétipos e o Inconsciente Coletivo. Petrópolis: Vozes, 2011.

JUNG, Carl Gustav. O Eu e o Inconsciente. Petrópolis: Vozes, 2011.

${ }^{9}$ Não são estas as palavras, mas este o sentido. As palavras são as seguintes: "Aos que entram nos mesmo rios outras e outras águas afluem; almas exalam do úmido" (HERÁCLITO apud ARIO DÍDIMO, em EUSÉBIO, Preparação Evangélica, XV, 20, In: Os Pensadores: Pré-Socráticos, 1991, p. 52).

${ }^{10}$ Como salienta o filósofo da Ciência Osvaldo Pessoa Junior, um aspecto fundamental do Princípio de Incerteza desenvolvido por Heisenberg é o Distúrbio Interacional. O observador sempre provoca um distúrbio no objeto na medição que segue à observação (PESSOA JUNIOR, 2006, p.78). Contudo, Heisenberg tratava então apenas do universo quântico. Em suas próprias palavras: "a interação entre observador e objeto causa alterações incontroláveis e grandes no sistema sendo observado, por causa de alterações descontinuas características dos processos atômicos" (HEISENBERG, Os Princípios Físicos da Teoria dos Quanta, 1930, p.3, nota 32 apud PESSOA JUNIOR, 2006, pp. 78 e 79).

${ }^{11}$ É preciso entender que proposições contraditórias podem mesmo ser irredutíveis em seus argumentos centrais, porém isto não impede de apresentarem elementos acessórios comuns ou, em todo caso, associáveis, que então funcionariam enquanto um eixo de articulação e combinação de todas elas.

${ }^{12} \mathrm{O}$ que Greene quer dizer é que o presente nada mais é que uma lista atual de agoras em nossa mente. Basta estarmos em movimento relativo que a minha não é igual a sua. Mas as duas listas são igualmente válidas. O passado e o futuro são dados em relação ao presente. Consequentemente, o passado e o futuro também são pessoais, mas todos igualmente válidos. Contudo, presente, passado e futuro não constituem realidades físicas no mundo, sendo apenas construção mental dada a partir de determinadas referências. $\mathrm{O}$ que de fato existe, quer dizer, extramentalmente, é o contínuo espaço-tempo enquanto um todo. 
${ }^{13}$ Nossa linha de mundo, como estuda Michio Kaku (2000, p. 262), sintetiza toda a nossa história, do nascimento à morte. Se estamos em estado de repouso em relação ao espaço, deitados numa cama por exemplo, nossa linha de mundo é uma linha vertical, pois estamos em deslocamento apenas em relação ao tempo. Se deixamos este estado, por, por exemplo, simplesmente estarmos andando ou indo de carro para algum lugar, nossa linha de mundo se torna uma linha inclinada, pois agora estamos também em deslocamento em relação ao espaço. Quanto mais depressa nos movemos mais inclinada se torna nossa linha de mundo. A rapidez máxima com que é possível se mover numa linha de mundo é a velocidade da luz no "vácuo". Velocidade que, no entanto, só pode ser alcançado pela própria luz. Em todo caso, mediante o Limite Superior, parte do diagrama de espaço-tempo é "proibida", ou seja, é preciso se mover numa velocidade maior que a da luz no "vácuo" para se entrar nessa zona proibida.

${ }^{14}$ Com efeito, na visão einsteiniana, nossa linha de mundo na realidade nunca realmente começa ou acaba. Mesmo quando morremos, as linhas de mundo das moléculas de nosso corpo continuam. Elas poderão se dispersar no ar ou no solo, mas irão traçar suas intermináveis linhas de mundo. De forma similar, quando nascemos, as linhas de mundo das moléculas que vêm de nossa mãe e as que vêm das moléculas de nosso pai se fundem num bebê. Assim, segundo Einstein, as linhas de mundo não se rompem nem aparecem do nada em ponto algum (KAKU, 2000, p.260).

${ }^{15}$ É preciso informar que tal experimento foi posto em prática pela primeira vez, em 1986, por Hellmuth et al no instituto Max Planck, perto de Munique, tendo então sido confirmado inteiramente as escolhas retardadas previstas por Wheeler, portanto, o princípio da reversibilidade do colapso nela implícito se mostrou consistente com a experimentação.

${ }^{16}$ Não que, cabe ressaltar, esteja fazendo eco à perspectiva do próprio John Wheeler. Não mesmo! Enquanto Wheeler defende que o passado é pura potência, sendo atualizado apenas no presente; afirmo que é já ato, mas retorna à potência e, então, pode ser re-atualizado de uma forma diferente.

${ }^{17}$ No caso eu mesmo, em minha Dissertação de Mestrado transformada em livro: TÔRRES, Moisés Romanazzi. Dante e o Princípio das Duas Beatitudes (Texto-Base de Comentário à Filosofia Política de Dante Alighieri). São Paulo: Nelpa, 2014.

${ }^{18}$ É evidente que as possibilidades e subpossibilidades, ainda que especulativas, portanto, dadas mediante intuição, se apresentam ao historiador na medida em que este aprofunda o conhecimento de seu objeto de estudo, no caso, do pensamento de Dante com suas implicações políticas e ideológicas, sendo assim igualmente, como aliás já dito, produto de investigação científica rigorosa. 